J. Perinat. Med. 16 (1988)

\section{Neonatal complications in small-for-gestational age neonates}

\author{
Arja Tenovuo
}

Department of Pediatrics, University Central Hospital of Turku, Turku, Finland

\section{Introduction}

The small-for-gestational age (SGA) neonate, both term and preterm, is vulnerable to many perinatal complications which may affect later development $[1,13,16,24,25]$. The SGA infant may run an increased risk for neonatal hazards $[6,13,19]$, although not all reports in the literature support this concept $[5,15]$. Intrauterine growth retardation (IUGR) can also be viewed as an adaptation process in which the size of the fetus may be appropriate to the availability of nutrients and thus lower the risk of hypoxic injury [28]. In addition, prenatal screening of IUGR as well as fetal monitoring during pregnancy and labor may help to avoid neonatal complications in SGA infants.

The purpose of the present study was to evaluate the incidences of neonatal complications in severely SGA neonates during the current policy of obstetric monitoring and in the presence of modern neonatal care. The study design was a prospective case-control model based on regional births during 1985 .

\section{Study population and methods}

All severely SGA infants (birth weight below the 2.5 th percentile on our fetal growth curve) born January 1 through December 31, in 1985, in the catchment area of the University Central Hospital of Turku (UCHT) were included in the study. The control group consisted of the next infants born in the UCHT, matched for gestational age and mode of delivery. The control infants had a birth weight between the 10th and 90th percentiles on our fetal growth curve.

The UCHT serves as a tertiary center for mothers and infants at risk in a region of 460000 people.

\section{Curriculum vitae}

ARJA TeNOVuO was born in 1956 in Jaala, Finland and graduated from the Medical Faculty of the University of Turku in 1982. Since graduation she has been working at the Department of Pediatrics in the University Central Hospital of Turku. Her main interest has concentrated in neonatology, and her present ac-

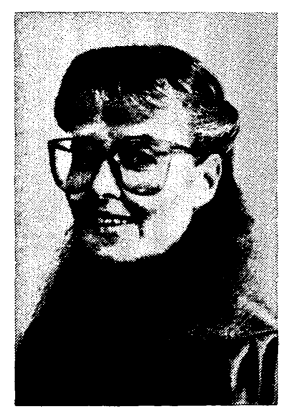

tivities deal with intrauterine growth retardation and its developmental aspects. She is a member of the Finnish Pediatric Association and the Finnish Perinatology Association.

About 5000 babies are delivered annually in this area, about 2500 of them in the UCHT and the remainders in 8 local hospitals with an obstetric unit. In 1985, the perinatal mortality rate was 8.7 per thousand and the neonatal mortality was 3.2 per thousand in the catchment area of the UCHT. The low birth weight (birth weight below $2500 \mathrm{~g}$ ) rate was $4.3 \%$ and the prematurity (gestational age less than 37 weeks) rate was $5.0 \%$. The cesarean section rate was $14.6 \%$.

Data on previous pregnancies and children, present pregnancy, maternal illnesses and other factors were collected. The gestational age of the infants was determined by the Dubowitz method [7]. The neurologic status of SGA infants and control infants was examined by the author after birth and at the age of 5-7 days [8].

Informed consent was obtained from the parents of the children who served as subjects of the in- 
vestigation. The study design was accepted by the ethical committee of the UCHT.

Asphyxia was diagnosed when Apgar scores were less than 5 at 5 minutes or when umbilical venous $\mathrm{pH}$ was below 7.25 at birth. Hypoglycemia was diagnosed when the blood glucose level was below $1.7 \mathrm{mmol} / 1$ both in preterm and in fullterm infants. The blood glucose levels were determined at the ages of 2, 6, 12 and 24 hours and later when indicated. Polycythemia was diagnosed, if the peak venous hemoglobin concentration was above 220 $\mathrm{g} / 1$ or venous hematocrit above $65 \%$ during the first 3 days of life. Hypocalcemia was diagnosed if the blood calcium level was below $1.8 \mathrm{mmol} / \mathrm{l}$ during the first three days of life. The criteria for hyperbilirubinemia was a bilirubin level exeeding $205 \mathrm{umol} / \mathrm{l}$ or necessitating therapeutic intervention. Abnormal neonatal neurologic signs included repeated tremors, jitteriness, hypotonia or hypertonia observed by the author both in the SGA group and in the control group during the first week of life.

Brain ultrasound scanning, echocardiography and EEG were carried out in the study group during the first week of life. In the control group these investigations were done only when clinically indicated. Urine samples were collected from all infants to screen for cytomegalovirus infection. To detect intrauterine infections among SGA infants blood samples were taken for measurement of toxoplasma, rubella, cytomegalo and herpes antibodies. Urine samples were collected during the first day of life and blood samples during the first three days of life. A chromosome culture was taken if there was clinical suspicion of abnormality.

Rohrer's ponderal index $(100 \times$ birth weight/birth length ${ }^{3}$ ) was used to classify the SGA infants into two categories: 1) proportionally growth retarded or type I growth retardation and 2) disproportionally growth retarded or type II growth retardation [26].

\section{Statistical analysis}

The McNemar test was used to compare the incidences of neonatal complications in the SGA and control infants [4]. The statistical significance of the odds ratio was tested with the exact binomial test and its confidence limits were calculated on the binomial parameters. Fisher's exact test was used in statistical analysis within the SGA group.

\section{Results}

During the study period, 118 severely SGA infants were born, which consisted of $2.3 \%$ of all births in the UCHT area. The mean gestational age of both SGA and control infants was 38.8 weeks (27-42 weeks). Eight of the SGA infants were born prematurely. The SGA group consisted of 74 girls and 44 boys and the control group of 56 girls and 62 boys. This difference was not statistically significant. Thirteen SGA infants were born from

Table I. Neonatal complications among SGA and control infants

\begin{tabular}{|c|c|c|c|c|c|}
\hline & $\begin{array}{l}\text { SGA } \\
n=118\end{array}$ & $(\%)$ & $\begin{array}{l}\text { Controls } \\
\mathrm{n}=118\end{array}$ & $(\%)$ & $\mathrm{p}$ \\
\hline Asphyxia & 19 & $(16.1)$ & 10 & $(8.5)$ & NS \\
\hline Hypoglycemia & 15 & (12.7) & 3 & $(2.5)$ & $<0.01$ \\
\hline Infections & 9 & $(7.6)$ & 4 & (3.3) & NS \\
\hline Polycythemia & 9 & (7.6) & 1 & & $<0.05$ \\
\hline Malformations & 8 & (6.8) & 0 & & $<0.01$ \\
\hline $\mathrm{ICH}$ & 2 & (1.7) & 1 & $(0.8)$ & NS \\
\hline Neurol abnormalities & 8 & $(6.8)$ & 1 & $(0.8)$ & $<0.05$ \\
\hline Breathing difficulties & 6 & $(5.1)$ & 5 & (4.2) & NS \\
\hline Hyperbilirubinemia & 13 & $(11.0)$ & 18 & $(15.2)$ & NS \\
\hline Hypocalcemia & 3 & $(2.5)$ & 1 & $(0.8)$ & NS \\
\hline Hypothermia & 5 & (4.2) & 1 & $(0.8)$ & NS \\
\hline Aspiration syndrome & 2 & (1.7) & 0 & & NS \\
\hline
\end{tabular}

$\mathrm{ICH}=$ intracranial hemorrhage

$\mathrm{NS}=$ not significant 
twin pregnancies. Of the total of 118 severely SGA neonates $72(61 \%)$ were born in the UCHT. Of these infants $30(42 \%)$ were diagnosed antenatally. Of all 118 SGA infants $35(30 \%)$ were diagnosed before delivery.

Hypoglycemia, polycythemia and abnormal neonatal neurologic signs were found significantly more often in SGA infants than in controls ( $p$ $<0.05-0.01$ ). The frequency of asphyxia was higher in the SGA group than in the control group, but the difference was not statistically significant. Chromosomal and other malformations were also more frequent in the SGA neonates than in controls $(\mathrm{p}<0.01)$ (Table I). Chromosomal abnor-

Table II. Crude relative odds ratios and $95 \%$ confidence intervals for neonatal complications in SGA infants

\begin{tabular}{lll}
\hline & $\begin{array}{l}\text { Odds } \\
\text { ratio }\end{array}$ & $\begin{array}{l}95 \% \\
\text { confidence } \\
\text { interval }\end{array}$ \\
\hline Asphyxia & 2.0 & $0.9-5.1$ \\
Hypoglycemia & 5.0 & $1.4-26.9$ \\
Infections & 6.0 & $0.7-276.7$ \\
Polycythemia & 9.0 & $1.2-399.0$ \\
ICH & 2.0 & $0.1-118.0$ \\
Neurol abnormality & 8.0 & $1.1-356.1$ \\
Breathing difficulty & 1.3 & $0.3-6.3$ \\
Hyperbilirubinemia & 0.7 & $0.3-1.6$ \\
Hypocalcemia & 3.0 & $0.2-157.7$ \\
Hypothermia & 5.0 & $0.6-237.1$ \\
\hline
\end{tabular}

$\mathrm{ICH}=$ intracranial hemorrhage malities in SGA group included one infant with trisomy 18 (died at the age of 6 days), one infant with chromosome 9 abnormality (died at the age of 6 months) and one infant with Down syndrome. One infant had fetal alcohol syndrome and one child was blind without any known cause. Two SGA infants had cleft palate and one had claw foot operated at the age of two days. SGA infants had a five-fold risk for hypoglycemia, a nine-fold risk for polysysthemia and an eight-fold risk for abnormal neonatal neurologic status compared to control infants (Table II).

No association was found between maternal factors such as toxemia $(\mathrm{n}=17)$, pyelonephritis $(n=7)$, short stature $(n=25)$, other diseases $(n=10)$ or smoking $(n=42)$ and the rate of neonatal complications among SGA infants. There were 66 infants with ponderal index below the 10th percentile and 52 infants with ponderal index above the 10th percentile. No difference in neonatal complications between these two groups of SGA infants was found. SGA boys suffered more frequently from hypoglycemia than the girls $(\mathrm{p}<0.05)$ (Table III).

Brain ultrasound scanning was carried out in 103 SGA infants and 19 of the scannings (18\%) were abnormal. Two infants had intracranial hemorrhage, one with gestational age of 36 weeks and the other of 39 weeks. Both were symptomatic. Other abnormal findings consisted of increased echodensities $(\mathrm{n}=11)$ and dilatated ventricles $(n=5)$. Infants with increased echodensity as well

Table III. Neonatal complications in SGA girls and SGA boys

\begin{tabular}{|c|c|c|c|c|c|}
\hline & \multicolumn{2}{|c|}{ Girls $(N=74)$} & \multicolumn{2}{|c|}{ Boys $(\mathrm{N}=44)$} & \multirow[b]{2}{*}{$\mathrm{p}$} \\
\hline & $\mathrm{N}$ & $(\%)$ & $\mathrm{N}$ & $(\%)$ & \\
\hline Asphyxia & 9 & $(12.2)$ & 10 & (22.7) & NS \\
\hline Hypoglycemia & 4 & $(5.4)$ & 11 & $(25.0)$ & $<0.01$ \\
\hline Infections & 6 & (8.1) & 3 & $(6.8)$ & NS \\
\hline Polycythemia & 5 & (6.8) & 4 & (9.1) & NS \\
\hline Malformations & 2 & (2.7) & 6 & (13.6) & $<0.05$ \\
\hline $\mathrm{ICH}$ & 1 & (1.4) & 1 & (2.3) & NS \\
\hline Neurol abnormalities & 6 & $(8.1)$ & 2 & (4.5) & NS \\
\hline Breathing difficulties & 4 & (5.4) & 2 & (4.5) & NS \\
\hline Hyperbilirbinemia & 9 & $(12.2)$ & 4 & $(9.1)$ & NS \\
\hline Hypocalcemia & 2 & $(2.7)$ & 1 & (2.3) & NS \\
\hline Hypothermia & 3 & (4.1) & 2 & (4.5) & NS \\
\hline Aspiration syndrome & 1 & (1.4) & 1 & (2.3) & NS \\
\hline
\end{tabular}

$\mathrm{ICH}=$ intracranial hemorrhage

NS $=$ not significant 
as those with dilatated ventricles had a normal brain ultrasound scanning in the control examination at the age of $1-3$ months. EEG was carried out in 91 SGA infants and abnormal findings were obtained in 5 cases.

Cesarean section was carried out in 14 cases (39\%) of antenatally diagnosed SGA infants $(n=35)$, while in those not antenatally diagnosed $(\mathrm{n}=83)$ cesarean section was done in 18 cases $(22 \%)$ $(p<0.05)$. Of the 14 cesarean sections with a recognized SGA fetus, five operations were emergencies during induced labor. Correct prenatal diagnosis of IUGR did not decrease the total neonatal complication rate in these infants compared to the SGA infants as a whole.

No congenital infections were found among SGA infants. One SGA infant had acquired cytomegalovirus infection, probably through blood transfusions. SGA infants born to small mothers (height less than $160 \mathrm{~cm}$ ) did not have significantly more neonatal complications than other SGA infants.

\section{Discussion}

One hundred and eighteen severely SGA infants and 118 control infants were investigated prospectively to evaluate the incidence of neonatal complications in the presence of the current policy of obstetric monitoring and neonatal management. The number of SGA girls was higher than that of SGA boys. The difference, although not statistically significant, may be due to the fact the same fetal growth curve was applied for both girls and boys.

Asphyxia has been considered the most serious perinatal complication in SGA infants. The additive interaction between asphyxia and IUGR has been found in retrospective studies from Sweden to be one of the main causes of cerebral palsy [11]. QUENSTED et al [22] reported that $31.5 \%$ of SGA fetuses had clinical signs of fetal distress during labor compared to $13.4 \%$ of AGA controls, but Eggermont et al [9] found no difference in the incidence of birth asphyxia between SGA and AGA infants. Asphyxia was found in the present study in $16 \%$ of the severely SGA infants and in $8.5 \%$ of control infants. The difference was not statistically significant, but in both groups the rate of asphyxia seems to be lower than in previous reports $[1,16,26,27]$. No association was found between the type of growth retardation and the frequency of asphyxia, although SGA infants with disproportionate growth retardation have been reported to suffer more often from asphyxia [27].

In the present study hypoglycemia was found in $13 \%$ of severely SGA infants. LUBCHENKO and BARD [18] reported a $25 \%$ incidence of hypoglycemia in term SGA neonates and a $40 \%$ incidence rate in preterm SGA neonates, while the incidence of hypoglycemia was $10 \%$ in term AGA neonates and $3 \%$ in preterm AGA neonates. KoIvisTo et al [17] reported that about half of hypoglycemic SGA infants were symptomatic, but other reports have found asymptomatic hypoglycemia rare $(5 \%)$ in SGA neonates $(15 \%)$. In the present study nine $(64 \%)$ of the hypoglycemic SGA infants were symptomatic. Our policy of early feeding of SGA infants includes $10 \mathrm{ml}$ of $10 \%$ glucose solution in the first 2 hours after birth and $10 \mathrm{ml}$ of breast milk during the first 5 hours after birth. This early feeding probably has reduced the frequency of hypoclycemia in SGA neonates.

No congenital viral infections were found in SGA neonates, which is in agreement with the results of previous reports $[2,20]$. Neonatal polycythemia is found in $4-5 \%$ of all newborns and $15-18 \%$ of term SGA newborns [12, 23]. Polycythemia is often related to hypoglycemia and later developmental abnormalities [3]. In this study $7.6 \%$ of SGA infants had polycythemia.

A low incidence of breathing difficulties in SGA group was found, not different from that of the control infants. SGA infants usually have mature lungs at birth and a low frequency of breathing difficulties [10]. Meconium aspiration syndrome has been reported often in SGA infants, but it was rare in this study. Presumably the apparent rarity of the meconium aspiration syndrome is a reflection of the relatively low incidence of asphyxia. In agreement with our results, intraventricular hemorrhage has been rare in earlier studies of SGA infants [22]. The results suggest that routine brain ultrasound scanning in asymptomatic SGA infants is not indicated.

A high incidence of congenital malformations $(6.7 \%)$ was found in SGA infants. None of the cases were diagnosed antenatally. Two of the malformations were fatal. Ounsted et al [19] have reported the incidence of congenital malformations in SGA newborns to be $6.9 \%$, which is about 3.5 times higher than that of the normal popula- 
tion. In another study, only $4 \%$ of term severely SGA infants were found to have recognizable malformations [15].

JONES and ROBERTON [15] reported the incidence of hypothermia to be $23 \%$ in severely SGA neonates, whereas in our study it was only $4.2 \%$. Temperature monitoring is necessary after birth in severely SGA infants. In our obstetric units, we start to warm up a SGA infant immediately after birth and thus hypothermia is rare. No difference was found in the incidence of hyperbilirubinemia between the control group and the SGA group. HoDGMAN et al [14] found consistently lower mean bilirubin values in SGA than in AGA infants with BW less than $1500 \mathrm{~g}$.
The cesarean section rate was high in SGA infants, especially in those who were diagnosed before delivery. This is probably due to more active intervention in recognized high risk pregnancies. However, the complication rate was comparable in SGA infacts both diagnosed and not diagnosed antenatally.

In conclusion, $42 \%$ of severely SGA infants had neonatal problems compared to $18 \%$ of control infants. Although careful monitoring of pregnancies and deliveries as well as advanced neonatal care are decreasing the incidence of various neonatal complications, severely SGA infants still run an increased risk and need special attention.

\section{Summary}

A prospective case-control study was carried out in 118 severely small-for-gestational age (SGA) infants and in 118 control infants born during 1985 in the catchment area of the University Central Hospital of Turku to investigate the neonatal complication rate in SGA infants during modern obstetric and neonatal care. All SGA infants had a birth weight below the 2.5 th percentile in our fetal growth curve and the control infants were matched for gestational age and mode of delivery. Neonatal complications were found in $42 \%$ of SGA neonates compared to $18 \%$ of control infants. Hypoglycemia, polycythemia and abnormal neurologic symptoms were more frequently found in SGA neonates than in control neonates. Asphyxia was found in $16 \%$ of SGA infants and in $8.5 \%$ of control infants. A five-fold risk for hypoglycemia and a eight-fold risk for abnormal neonatal neurologic signs in SGA infants were found. SGA boys had more often asphyxia (22\% versus $12 \%)$ and hypoglycemia ( $25 \%$ versus $5 \%)$ than SGA girls. The antenatal diagnosis of SGA infant was made in 35 cases $(30 \%)$. Of these diagnosed infants 14 were delivered by cesarean section $(39 \%)$, while the cesarean section rate in all SGA infants was $27 \%$. Although antenatal diagnosis of poor intrauterine growth did not decrease the neonatal complication rate, the antenatal diagnosis resulted in more active intervention during delivery. The SGA infants still run an increased risk for complications during delivery and neonatal period and need special attention.

Keywords: Asphyxia, hypoglycemia, intrauterine growth retardation, neonatal complications, small-for-gestational age infant.

\section{Zusammenfassung}

\section{Neonatale Komplikationen bei Small-for-date-Kindern}

Um die Häufigkeit von neonatalen Komplikationen zu erfassen, wurde eine fallkontrollierte prospektive Studie mit 118 Small-for-date-Kindern sowie 118 Kontrollkindern durchgeführt. Sie wurden 1985 im Einzugsgebiet der Universitätsklinik von Turku geboren, wo moderne geburtshilfliche und neonatale Überwachungsmethoden zur Verfügung stehen. Alle Kinder, die als für das Gestationsalter zu klein (= SGA-Kinder) eingestuft wurden, lagen unterhalb der 2.5-er Perzentile unserer Wachstumskurve. Die Neugeborenen der Kontrollgruppe wurden ihnen nach dem Gestationsalter sowie dem Entbindungsmodus zugeordnet. Neonatale Komplikationen traten bei $42 \%$ der SGA-Kinder auf, in der der Kontrollgruppe nur bei $18 \%$. Ebenso waren Hypoglykämien,
Polyzythämien und auffällige neurologische Symptome bei den SGA-Kindern häufiger anzutreffen als in der Kontrollgruppe. $16 \%$ der SGA-Gruppe und $8.5 \%$ der Kontrollkinder hatten eine Asphyxie. Bei den SGA-Kindern war das Hypoglykämie-Risiko fünfmal höher. Das Risiko hinsichtlich auffälliger neurologischer Zeichen war um ein achtfaches erhöht. Männliche SGA-Kinder hatten häufiger Asphyxien (22\% versus $12 \%$ ) und $\mathrm{Hy}$ poglykämien ( $25 \%$ versus $5 \%$ ) als SGA-Mädchen. Antenatal wurde die Wachstumsretardierung in 35 Fällen $(30 \%)$ erkannt. Von diesen diagnostizierten Fällen wurden $14(39 \%)$ per Sectio entbunden. Auf alle SGAKinder bezogen, betrug die Sectio-Rate $27 \%$. Wenn auch die antenatale Diagnose einer Wachstumsretardierung nicht die neonatale Komplikationsrate herabsetzte, so 
führte sie doch zu einem aktiveren Vorgehen während der Entbindung. SGA-Kinder haben immer noch eine höhere Komplikationsrate während der Geburt und
Neonatalphase und benötigen eine intensive Überwachung.

Schlüsselwörter: Asphyxie, Hypoglykämie, intrauterine Wachstumsretardierung, neonatale Komplikationen, Smallfor-date-Kinder.

\section{Résumé \\ Complications néonatales chez les nouveaux-nés hypo- trophes}

On a réalisé une étude prospective contrôlée chez 118 enfants avec une hypotrophie sévère (S. G. A.) et chez 118 enfants contrôles nés en 1985 dans l'aire de recrutement de l'Hôpital Central Universitaire de TURKU pour étudier le taux de complications néonatales chez les enfants S.G.A. recevant des soins obstétricaux et néonataux modernes. Tous les enfants S. G. A. avaient un poids de naissance inférieur au 2,5è percentile sur notre courbe de croissance fotale et les enfants contrôles ont été appariés pouir l'âge gestationnel et le mode d'accouchement. On a trouvé des complications néonatales chez $42 \%$ des nouveaux-nés S. G. A. et chez $18 \%$ des enfants contrôles. Hypoglycémie, polyglobulie et symptomes neurologiques anormaux sont plus souvent retrouvés chez les nouveaux-nés S. G. A. que chez les nouveaux-nés contrôles. On a trouvé une asphyxie chez
$16 \%$ des enfants S.G. A. et chez $8,5 \%$ des enfants contrôles. L'hypoglycémie est cinq fois plus fréquente etles signes neurologiques anormaux chez le nouveauné, huit fois plus fréquents chez les enfants S. G. A.

Les garçons S.G.A. présentent plus souvent une asphyxie $(22 \%$ versus $12 \%)$ et une hypoglycémie $(25 \%$ versus $5 \%$ ) que les filles $\mathrm{S}$. G. A. Le diagnostic prénatal de R.C.I.U. a été porté dans 35 cas $(30 \%)$; parmi ces enfants, 14 sont nés par césarienne $(39 \%)$ alors que le taux de césarienne pour l'ensemble des enfants S. G. A. est de $27 \%$.

Bien que le diagnostic prénatal de retard de croissance intra-utérin ne diminue pas le taux de complications néonatales, le diagnostic prénatal entraîne une intervention plus active en cours d'accouchement. Les enfants S. G. A. courent encore un risque accru de complications pendant l'accouchement et la période néonatale et ils neceesitent une attention particulière.

Mots-clés: Asphyxie, complications néonatales, hypoglycémie, hypotrophie, retard de croissance intra-utérin.

Acknowledgement: This study was supported by a grant from the Rinnekoti Research Foundation. The author wishes to thank Heikki Korvenranta, M. D. and Pentti Kero, M. D. for their great help.

\section{References}

[1] AlLEN MC: Developmental outcome and followup of the small for gestational age infant. Semin Perinat 8 (1984) 123

[2] ANDReasson B, NW Svenningsen, E NoRdenfelt: Screening for viral infections in infants with poor intrauterine growth. Acta Pediatr Scand 70 (1981) 673

[3] Black VD, LO Lubchenko, DW Luckey, BL Koops, GA McGuinness, DP Powell, AL TomLINSEN: Developmental and neurologic sequelae of neonatal hyperviscosity syndrome. Pediatrics 69 (1982) 426

[4] BRESLOW NE, NE DAY: Statistical methods in cancer research. Vol. 1. The analysis of case-control studies. Int. agency for research cancer, Lyon (WHO) 1980

[5] Calame A, S Ducret, L Jaunin, B Plancherel: High risk appropriate for gestational age (AGA) and small for gestational age (SGA) preterm infants. Helv Paediatr Acta 38 (1983) 39

[6] Cassidy M, S BaKer, J Stack, H Murphy: Risk factors and perinatal problems in small for gesta- tional age pregnancies. Ir J Med Science 154 (1985) 237

[7] Dubowitz L, V Dubowitz, C Goldberg: Clinical assessment of gestational age in the newborn infant. Pediatrics 77 (1970) 1

[8] Dubowitz L, V Dubowitz: The neurological assessment of the preterm and full-term newborn infant. Clinics Dev Med 79. London. Heineman. 1980

[9] Eggermont E, H Devlieger, L Standaert, AM Delaere-van Hee, L Snoek, S Bhavani, J Jaeken: The neonate who is small for gestational age. In: FA Asshe, WB ROBERTSON (eds): Fetal growth retardation. Churchill Livingstone, New York 1981

[10] GLUCK L, MV KuLowICH: Lecithin/sphingomyelin ratios in amniotic fluid in normal and abnormal pregnancies. Am J Obstet Gynecol 115 (1973) 539

[11] HAGBerg G, B HaGBerg, I Olow: The changing panorama of cerebral palsy in Sweden 1954-1970. III. The importance of foetal deprivation of supply. Acta Paediatr Scand 65 (1976) 403

[12] HaKANSON DO, W OH: Hyperviscosity in small-forgestational age infants. Biol Neonat 37 (1980) 109 
[13] Heinonen K, R Matilainen, H Koski, K LauniALA: Intrauterine growth retardation in preterm infants. J Perinat Med 13 (1985) 171

[14] Hodgman JE, PYK Wu, NB White, M Phil, DA BRYLA: Comparison of phototherapy results in small-for-gestational-age and appropriate-for-gestational-age infants weighing less than 2000 grams. Pediatrics [Supplement] 1985.

[15] JONES RAK, NRC ROBERTON: Small for dates babies: are they really a problem? Arch Dis Child 61 (1986) 877

[16] Jones RAK, NRC RoBerton: Problems of the small-for-dates baby. Clin Obstet Gynecol 11 (1984) 499

[17] KoIvisto M, B Blanco-Sequeiros, U Krause: Neonatal symptomatic and asymptomatic hypoglycemia: follow-up study of 51 children. Dev Med Child Neurol 14 (1972) 603

[18] LUBCHENKO LO, H BARD: Incidence of hypoglycemia in newborn infants classified by birth weight and gestational age. Pediatrics 47 (1971) 831

[19] OUnsted M, V MoAR, WA ScotT: Perinatal morbidity and mortality in small-for-dates babies: the relative importance of some maternal factors. Early Hum Develop 5 (1981) 367

[20] PRIMHAK RA, RM Simpson: Screening small for gestational age babies for congenital infection. Clinical Ped 21 (1982) 417

[21] Procianoy RS, JA Garcia-Prats, JM Adams, A Silvers, AJ RudolPH: Hyaline membrane disease and intraventricular haemorrhage in small for gestational age infants. Arch Dis Child 55 (1980) 502
[22] Quensted M, C Quensted: Rate of intrauterine growth. Nature 220 (1978) 599

[23] SWEET AY: Classification of the low-birth-weight infant. In: MH KLAUS, AA FanAROFF (eds): Care of the high risk neonate. Third edition. W. B. Saunders Company, Philadelphia 1986

[24] Tenovuo A, P Kero, H Korvenranta, R ERKKola: Risk factors associated with severely small-for-gestational age neonates. Am J Perinatol 1988 (in press)

[25] Tenovuo A, P Kero, P PIekkala, H KorvenRANTA, M SillanPaA: Developmental outcome of 519 small-for-gestational age infants at the age of two years. Neuropediatrics 19 (1988) 41

[26] WALTHER FJ, LHJ RAMAEKERS: The ponderal index as a measure of the nutritional status at birth and its relation to some aspects of neonatal morbidity. J Perinat Med 10 (1982) 42

[27] WALTHER FJ, LHJ RAMAEKERS: Neonatal morbidity of SGA infants in relation to their nutritional status at birth. Acta Paediatr Scand 71 (1982) 437

[28] WARSHAW JB: Intrauterine growth retardation: Adaptation or pathology? Pediatrics 76 (1985) 998

Received October 9, 1987. Revised January 15, 1988. Accepted February 9, 1988.

Arja Tenovuo, M. D.

Department of Pediatrics

University Hospital of Turku

20520 Turku, Finland 


\begin{tabular}{|c|}
\hline New Journal \\
\hline Journal of \\
\hline Trace Elementsand \\
\hline Electrolytesin \\
\hline Healthand Disease \\
\hline
\end{tabular}

\section{Analytical Methods \\ Metabolism: Biochemistry Pathobiochemistry \\ Nutrition · Toxicology $\cdot$ Epidemiology \\ Clinical Application: Diagnosis Therapy}

Editors-in-Chief

Peter Brätter, Berlin, F. R. G.

Jürgen D. Kruse-Jarres, Stuttgart, F. R. G.

Ingrid Lombeck, Düsseldorf, F. R. G.

\section{Editorial Board}

P. J. Aggett, Great Britain · M. Anke, G. D. R.

G. M. Berlyne, U. S. A. · H. Bowen, Great Britain · J. L. Burguera, Venezuela

J. J. Canary, U. S. A. · J. H. J. Copius Peereboom, The Netherlands

D. M. Danks, Australia · G. S. Fell, Great Britain

L. E. Feinendegen, F. R. G. : W. Fresenius, F. R. G. · M. H. N. Golden, Jamaica

T. Günther, F. R. G. · K. M. Hambidge, U. S. A. · H.-J. Holtmeier, F. R. G.

M. Kirchgeßner, F. R. G. · B. Lönnerdal, U. S. A. · F. Manz, F. R. G.

O. Oster, F. R. G. · R. M. Parr, Austria · E. Sabbioni, Italy

P. Schramel, F. R. G. · F. W. Sunderman Jr, U. S. A. · Y. Tanaka, Canada

Y. Thomassen, Norway · G. Tölg, F. R. G. · J. Versieck, Belgium

A. Wendel, F. R. G. · G. L. Xu, China, G. Q. Yang, China · B. Zachara, Poland

\section{Subscription Information}

The first volume consists of 122 pages published in two issues in September and December 1987.

Subsequent volumes will comprise four issues with approx. 260 pages per calendar year.

1987: DM 140,-; approx. US $\$ 83.00 \cdot 1988$ : DM $280,-;$ approx. US $\$ 165.00$

Single issues are available at DM $80,-;$ approx. US $\$ 47.00$

Free sample copies available on request.

US dollar prices are subject to change without notice

\section{de Gruyter · Berlin · New York}

Genthiner Strasse 13, D-1000 Berlin 30 . Tel.: (030) 26005-0 . Telex 184027 . Telefax (030) 26005-251 200 Saw Mill River Road, Hawthorne, N.Y. 10532 - Tel.: (914) 747-0110 • Telex 646677 - Telefax (914) 747-1326 